\title{
ASSESSMENT OF CARRYING CAPACITY OF THE ROUND IN PLAN REINFORCED CONCRETE FOUNDATION FOR THE SILO
}

\author{
${ }^{1}$ Vybranets Yu., Ph.D, \\ yura.vybranets@gmail.com, ORCID ID: 0000-0002-3842-9780 \\ ${ }^{1}$ Vikhot S., PhD, \\ vixot@ukr.net, ORCID ID: 0000-0002-1063-2103 \\ ${ }^{1}$ Lviv Polytechnic National University \\ 12 Bandera street, Lviv, Ukraine, 79013 \\ ${ }^{2}$ Burchenya S., Ph.D., \\ nedostup@i.ua, ORCID ID: 0000-0002-6903-11348 \\ ${ }^{2}$ Lviv National Agrarian University \\ 1 V. Velykoho street, Dublyany, Ukraine, 30831
}

${ }^{3}$ Babyak I., Ph.D.,

igorbabyak@meta.ua, ORCID ID: 0000-0002-3732-2439

${ }^{3}$ State Enterprise "State Road Research Institute. M.P. Shulgin»"

57 Peremohy Ave., Kyiv, Ukraine, 03113

\begin{abstract}
During the design, installation and operation of silos, they have defects and damage of various kinds, which affect the stress-strain state and durability of structural elements. Timely inspections and determination of technical conditions of structural elements of the structure and the site as a whole, will establish the possibility of its further safe operation or the need to restore operational properties by ensuring structural safety and reliability of structures.

Therefore, the development of design schemes, methods of calculating the stress-strain state, life expectancy and further reinforcement for round reinforced concrete elements of silos with local damage, is quite relevant.

Improper maintenance and operation of structural elements, as well as errors in the design and installation in the future lead to unusable for normal operation and sometimes an emergency. The development of projects to strengthen existing structures is a very responsible matter.

The most common solution for strengthening existing foundations is to increase the area of support of the foundation cushion, which is not always possible in a compact building.

The purpose of the work is to determine the technical condition of the building structures of the silo and the results of calculations performed in the PC Lira, to offer options for strengthening the foundation on a specific example.

Structural solutions of the reinforced concrete monolithic foundation of the silo, the main defects and damages determined by the technical condition of the structure are given.

For further safe operation of the structure, it is recommended to reinforce the wall foundations by gluing composite tapes and perform reinforcement of the foundations by controlling the growth of piles in accordance with the additional working design of the structure reinforcement.

If the latest recommendations on strengthening and adhering to the safe and reliable operation of construction and structures are followed, further operation of building structures will be safe.

Keywords: reinforced concrete monolithic foundation, foundation walls, silo, reinforcement.

Introduction. Reliability and durability of monolithic reinforced concrete cylindrical silos are still relevant in connection with damage to walls, demolition of buildings, their reconstruction, design and construction of new types of silos.

Timely inspections and determination of technical conditions of structural elements of the structure and the object as a whole [1], will establish the possibility of its further safe operation or the need to restore performance by ensuring structural safety and reliability of structures [2].
\end{abstract}

Bulletin of Odessa State Academy of Civil Engineering and Architecture, 2021, no. 83, page 28-37 
There are cases of damage and even destruction of the walls of silos built in full compliance with design standards. This gives grounds to assert the need at this stage to conduct additional both theoretical and experimental studies to clarify the current loads from the bulk material, taking into account the adverse effects of the environment.

Analysis of recent research and publications. During the design, installation and operation of silos, they have different kinds of defects and damage, which affect the stress-strain state and durability of structural elements. [3]. Silos, hopper tanks, designed for storage of bulk materials, have been used for a long time, but the exact data on the stresses that appear in the walls of structures during their filling and unloading are still quite limited [4].

Nowadays, calculation methods and calculation schemes that reflect the impact of damage and defects that occur during using under the influence of an aggressive environment, have not been developed enough for practical application. There are no sections in the normative documents devoted to the calculation of reinforced concrete structures in general [5, 6], and the walls of silos in particular, exposed to aggressive operating environments. They only allow you to choose the means of protection of reinforced concrete depending on the degree of aggressive environmental impact.

One of the disadvantages of designing metal silos is the using of stiffening ribs, which contributes to the non-uniformity of the stress-strain state of the structure, as they make it difficult to manufacture the structure and subsequent operation of the tank. Therefore, the task of developing calculation schemes, methods for calculating the stress-strain state, improving the design concept, life expectancy and further strengthening of the elements of silos with local damage, is quite relevant [7].

Improper maintenance and using of structural elements, as well as errors in design and installation, further lead to unusable, and sometimes emergency, condition. The development of projects to strengthen existing structures is a very responsible matter. Specialists who do not have the appropriate experience and qualifications are often involved in such work, which leads to constructive decisions that are not effective.

The most common solution for strengthening existing foundations is to increase the area of the foundation, which is not always possible in a compact building.

The purpose of the work and the task. The purpose of the work is to determine the technical condition of the building structures of the silo and the results of the calculations carried out in the LIRA PC, to offer options for strengthening the foundation on a specific example.

The object of the study is a reinforced concrete monolithic foundation for a silo, round in plan, with a wall thickness of $600 \mathrm{~mm}$, which is supported by a tape reinforced concrete footing $2200 \mathrm{~m}$ wide and $600 \mathrm{~mm}$ thick. The diameter of the foundation walls in the axes is $21500 \mathrm{~mm}$, the inner diameter of the foundation walls is $20900 \mathrm{~mm}$, the outer diameter of the walls is $22100 \mathrm{~mm}$. The height of the foundation walls from the upper face of the footing to the lower face of the bottom of the silo is $2400 \mathrm{~mm}$.

Research methods. Based on the geological surveys and the obtained initial design documentation, it is necessary to calculate the boundary conditions of the first and second groups to determine the strength, stiffness and crack resistance and develop recommendations for strengthening the monolithic reinforced concrete foundation of the silo.

Research results. According to the structural scheme, the metal silo with monolithic reinforced concrete foundations. Next to it is another silo with similar dimensions and design (Fig. 1). To the south are two smaller silos. 


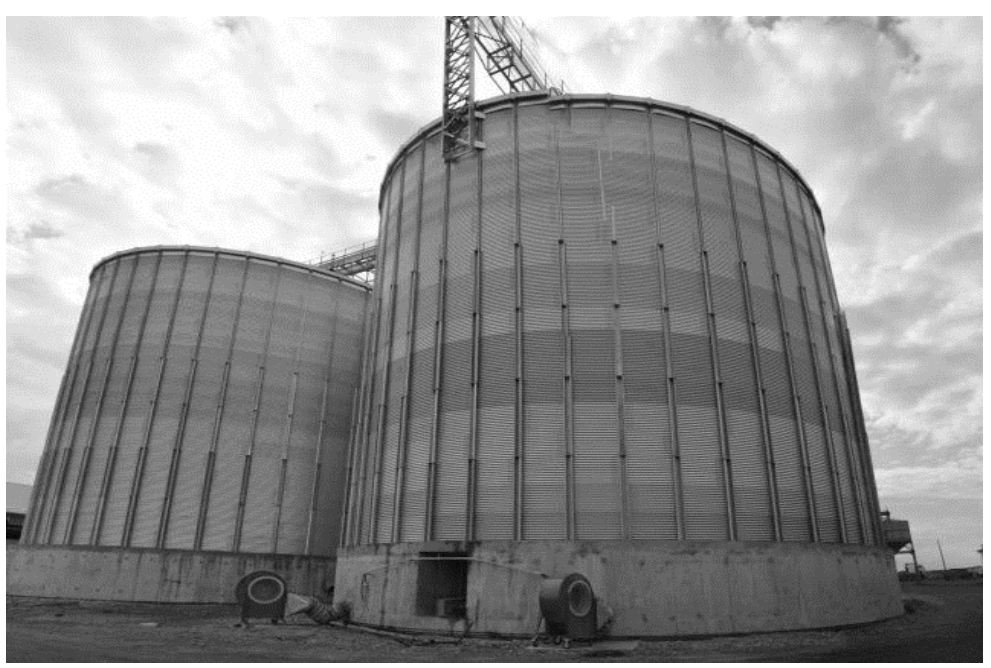

Fig. 1. General view of buildings

The walls of the silo are made of corrugated profiled decking, which rests on bent flat-shelf $\mathrm{C}$-shaped profiles with variable cross-section in height.

The payload from the grain in the silo is taken to be $50,000 \mathrm{kN}(2 / 3$ of the filling height of the metal part of the silo). The outer diameter of the silo foundation wall is $22 \mathrm{~m}$.

According to the design documentation, the reinforced concrete monolithic foundation is round in plan and arranged on a compacted gravel-sand mixture at a dry soil density of $1600 \mathrm{~kg} / \mathrm{m}^{3}$.

According to the project, the foundation for the silo is monolithic reinforced concrete. The footing according to the project is shifted relative to the axis by 1050 and $1150 \mathrm{~mm}$, respectively, from and to the center of the foundation. Therefore, the inner diameter of the footing is $19200 \mathrm{~mm}$, the outer diameter $-23600 \mathrm{~mm}$. The height of the foundation walls from the upper face of the footing to the lower face of the bottom of the silo is $2400 \mathrm{~mm}$ (Fig. 2).

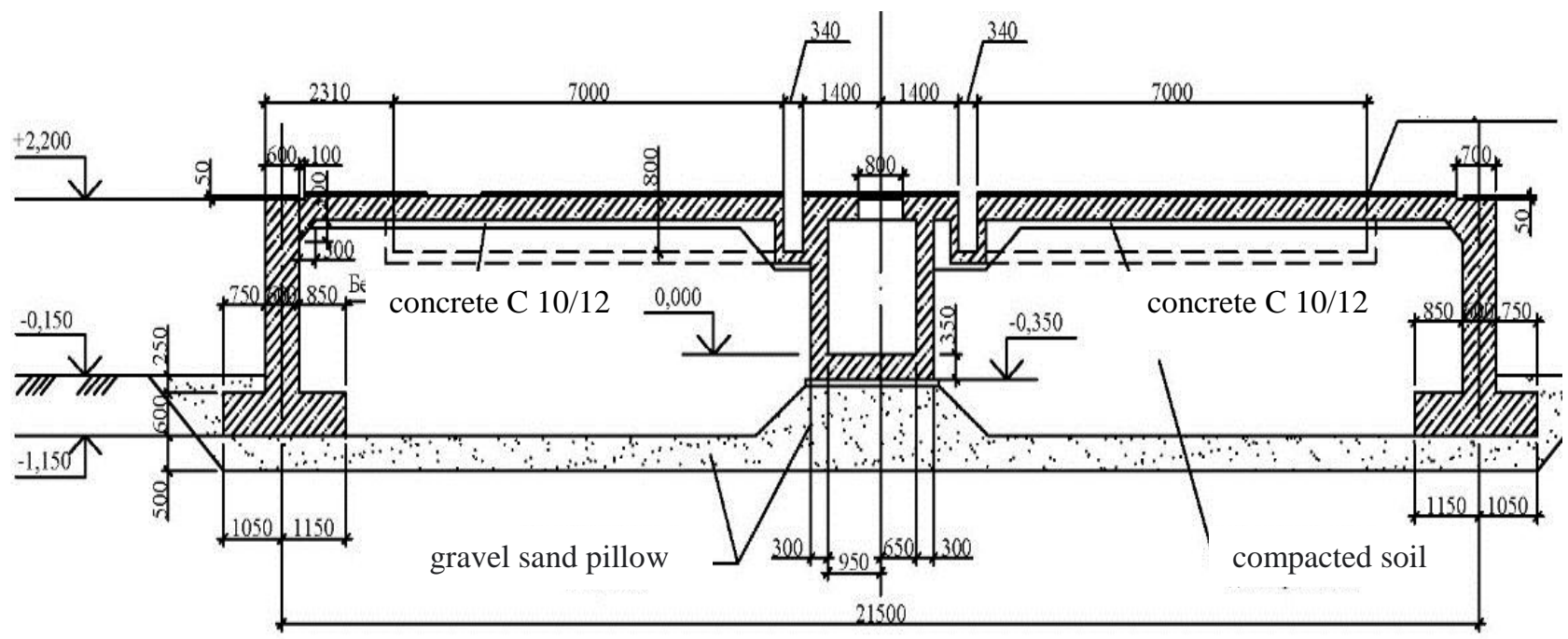

Fig. 2. Scheme of the foundation

The transitional gallery of the foundation is monolithic reinforced concrete. Its walls are $300 \mathrm{~mm}$ thick and $1800 \mathrm{~mm}$ high. Footing according to the project $350 \mathrm{~mm}$ thick. The bottom of the silo between the walls of the foundation is a monolithic reinforced concrete slab with a thickness of $350 \mathrm{~mm}$, which rests along the contour of the foundation walls and compacted soil.

According to the structural scheme, the reinforced concrete foundation, footing and bottom of the silo are one solid element in the form of a frame structure. 
The lower face of the footing is arranged according to the project at the level of $-1.0 \mathrm{~m}$ from the ground surface. The level of the clean floor of the transitional gallery is taken as 0.000 . According to the project, a reinforced concrete stage was arranged around the foundation wall.

As can be seen from the drawings of the technical documentation, the footing is reinforced with mesh with a diameter of $12 \mathrm{~mm}$ class A400C. Step of armature in a grid of $242 \ldots$ $296 \times 300 \mathrm{~mm}$.

The walls of the foundation are reinforced with horizontal and vertical bars with a diameter of $8 \mathrm{~mm}$ class A400C with a step of $350 \mathrm{~mm}$ along the height of the wall.

Geological studies at the site of technical inspection of the building were performed by Ukoopspilka PI Ukoopproekt of the Lviv VKP.

The study area is located within the Bugostyr plain. The terrain is flat.

According to the complexity geological conditions, the study area belongs to the II category.

Modern geological processes and adverse effects for construction on the site are missing.

Groundwater is infiltration, non-pressure, type "top", which is found in C.1, C.3. Intermediate water resistance is IGE-5 soils, which contributes to the accumulation of infiltration water of insignificant debit over IGE-5 (upper part of IGE-5 is soft-plastic up to $0.5 \mathrm{~m}$ ).

Soils IGE-3, IGE-4, IGE-5 are recommended as a basis for the foundation.

The recommended type of foundations is a monolithic slab, piles with replacement of IGE-2 soils with gravel-pebble mixture with layer-by-layer compaction.

Seismicity of the district -6 points (map ZSR-2004-A). Category of soils IGE-3, IGE-4, IGE-5 by seismic properties - II, soils IGE-2 - IV.

The main characteristics to be determined during the survey were: geometric dimensions of structures, subsidence of structures; width and length of crack opening, their location and nature; strength of concrete, location of reinforcement. A visual inspection of the aboveground part of the foundations revealed a number of cracks. The main cracks were located on the axis $2 \ldots 3$ between the axes A...B and on the axis $2 . .3$ between the axes Б...B (Fig. 3) with a width of opening up to $4.4 \mathrm{~mm}$. Cracks in the walls and the footing were also found in the gallery along the axis 2 between the axes A...B (Fig. 4) with a width of opening up to $1.9 \mathrm{~mm}$.

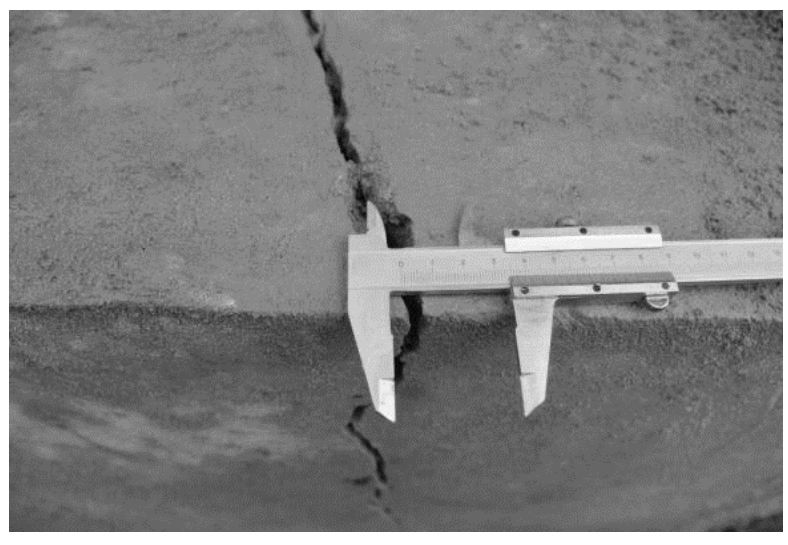

Fig. 3. The width of the opening of the crack of the foundation between the axes $2 \ldots 3$ along the axes A...B

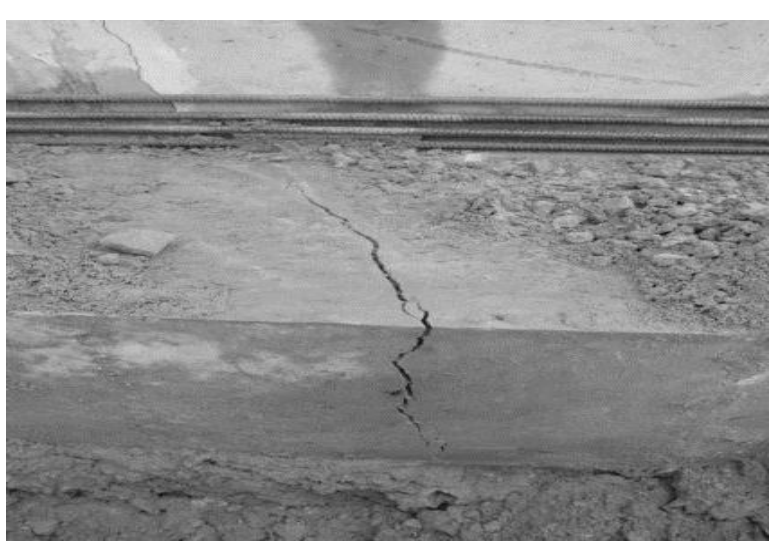

Fig. 4. The formation of a crack on the wall and the footing between the axes $2 \ldots 3$ along the axes A...B

The underground part of the building was visually inspected by excavation. The pits were arranged in places of cracks. During the visual inspection, the development of cracks up to $6 \mathrm{~mm}$ wide was detected (Fig. 5). It was also found that the structure in the axes A...B between the axes $1 \ldots 3$ is arranged on the loose soil (Fig. 6, Fig. 7). 


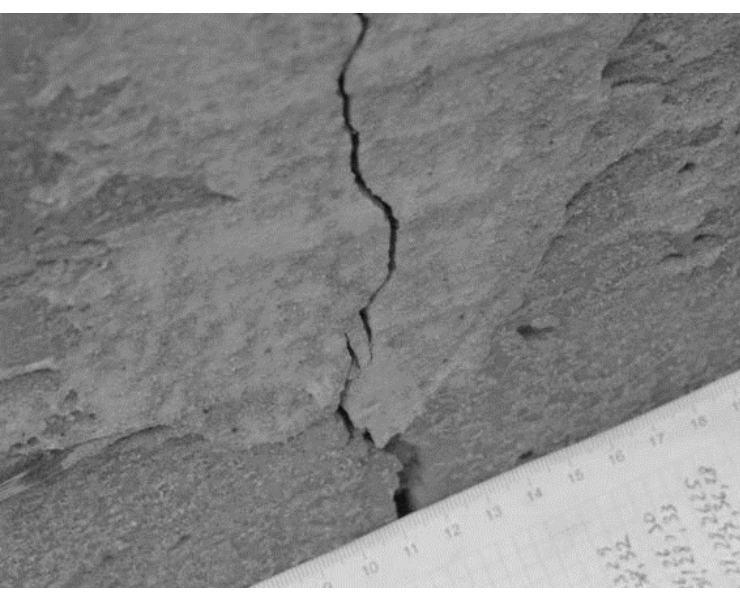

Fig. 5. Crack in the foundation between the axes $2 \ldots 3$ along the axes A...B

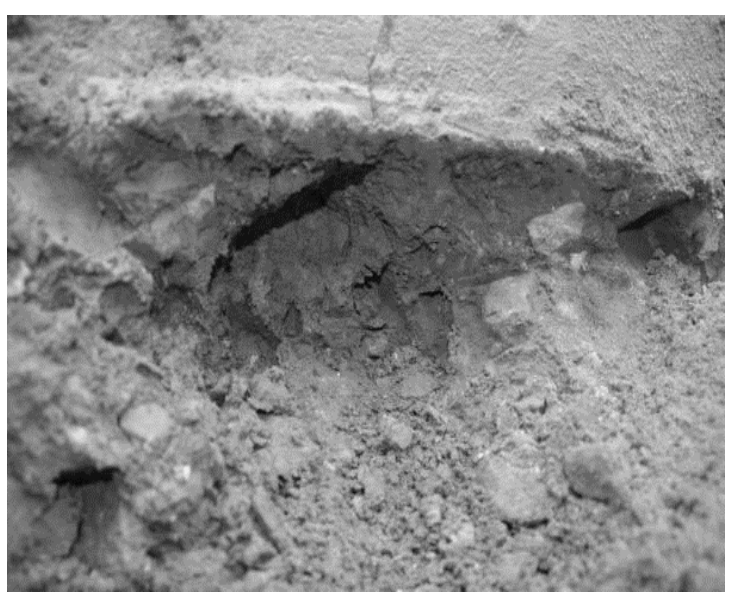

Fig. 6. Filling under the footing between the axes $1 \ldots 3$ along the axes A...B

When installing the pits, it was found that the footing is arranged at a depth of $560 \ldots 600 \mathrm{~mm}$ from the ground, although the project specifies the installation of a footing to a depth of $1.0 \mathrm{~m}$ from the ground. This depth of laying the footing contradicts the regulatory design requirements, which take into account the installation of foundations at a depth of at least $700 \ldots 800 \mathrm{~mm}$ for the region. However, it should be noted that the project provided for the installation of a strip foundation on a compacted gravel-sand mixture. As the results of the inspection [8] of the condition of the foundations showed, a limestone-sand mixed with the foundation soil was found under the footing. According to eyewitnesses, it is clear that the foundations were laid during the rainy season.

The process of crack development began during the operation of the facility, after $100 \%$ grain loading. The process of crack development run on now (Fig. 7).

Scan cracks on the A axis between the axes $1 . . .3$

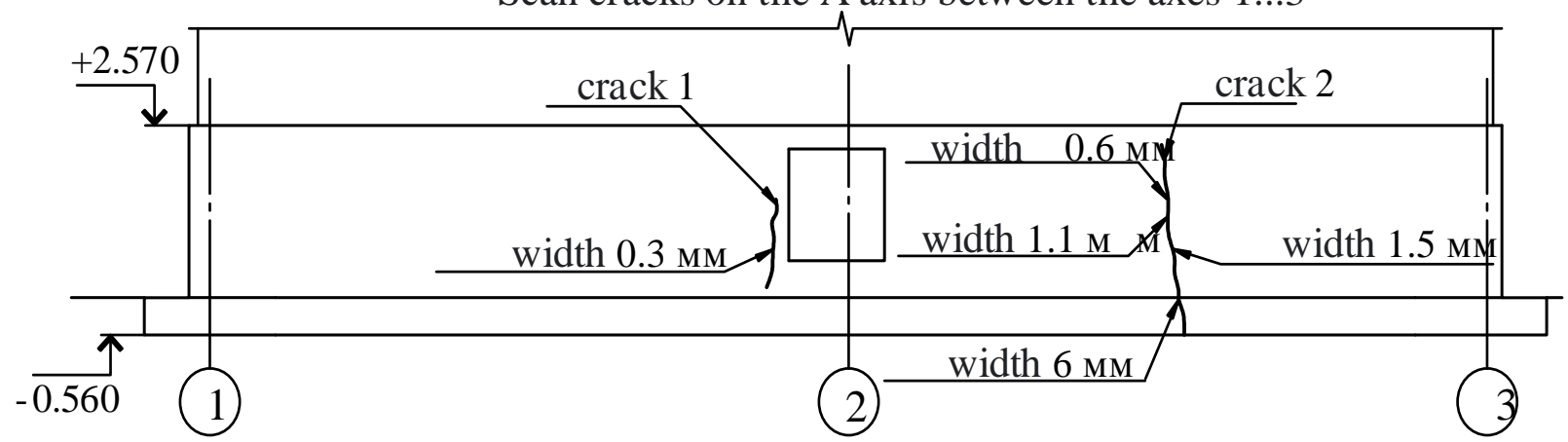

Scan cracks on the 3 axis between the axes A...B

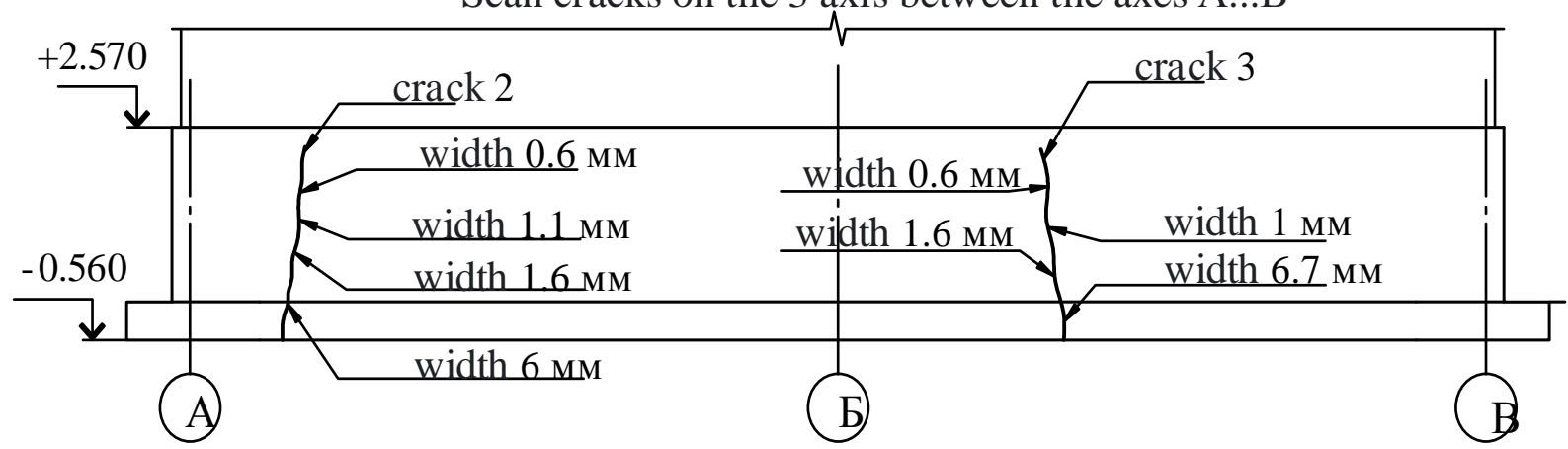

Fig. 7. Scheme of crack development on the walls of the foundation 
According to the results of geological studies, the structure is arranged on soft-plastic, peat, black loam and refractory, dark yellow loam.

However, it should be noted that the type of foundations is determined by the number of silos, the location of the columns of the silo floor, as well as the bearing capacity of the base soils.

The most common solution is the arrangement of foundations in the form of a continuous beamless slab of monolithic reinforced concrete with $0.2 \mathrm{D}$ brackets, where $\mathrm{D}$ is the diameter of a round or square silo. To install the columns of the silo floor on the plate, the arrangement of glasstype subcolumns is provided.

For round free-standing silos, the foundations are usually made in the form of a ring or a round concrete slab of class not lower than $\mathrm{C} 16 / 20$. If the time from the end of concreting the foundation slabs to the full load of the silos is at least three months, when calculating the foundation slabs it is recommended to take into account the increase in strength of concrete over time.

The location of the working bars of both rows is assumed to be mutually perpendicular. Round foundation slabs of free-standing foundations are reinforced with annular and radial working reinforcement. The annular foundations of free-standing silos are reinforced with radial working and annular structural reinforcement. It is recommended to accept working armature of base plates of silos from hot-rolled steel of periodic profile of the A400C class, constructive armature from hotrolled round smooth reinforcing steel of the A240C class.

It becomes obvious that when installing the pit under the foundations revealed deviations from the project, which is not expressed by ensuring the bearing capacity of the foundations for the following parameters:

- the foundation is made of non-compliant materials and without compaction;

- the level of the footing laying does not meet the design requirements;

- the building is arranged on peat soils.

The condition of structures is characterized by the presence of defects and damage. Taking into account the actual properties of materials meet the requirements of current regulations, which relate to the technical condition 3 - unsuitable for normal operation [9]. Damaged areas for further normal operation should be reinforced $[10,11]$.

The physical and mechanical properties of concrete elements generally correspond to a class C 16/20. External inspection and tapping revealed that the concrete is homogeneous and well compacted during concreting [12]. Reinforcement of the foundation walls corresponds to the project.

When performing technical inspections revealed in the lower part of the foundation wall reinforcing bars. This decision and its implementation does not allow to solve the problem of strengthening the foundation for subsidence, as well as tangential and radial forces.

According to the results of the walls scanning, it was found that in the foundation wall the reinforcement pitch is $300 \times 375 \mathrm{~mm}$, in the gallery wall $300 \times 300 \mathrm{~mm}$. Reinforcement $\varnothing 16$ A400C $\mathrm{mm}$ with a step of $270 \mathrm{~mm}$ was found in the footing.

According to the above factors, the structure is arranged on peat soils and constantly settles unevenly. Uneven subsidence contributes to the development of cracks in the foundation slab.

The results of the calculation on the LIRA PC (Fig. 8) showed an insufficient amount of reinforcement in the walls of the foundation on the action of longitudinal forces $(1220 \ldots 1380 \mathrm{kN})$, which contributes to the development of cracks in the walls of the foundation. Based even on the design requirements for the percentage of reinforcement, the cross-sectional area of the reinforcement in the foundation wall should be $45 \ldots 60 \mathrm{~cm}^{2}$ with a cross-section of $60 \times 167 \mathrm{~cm}$. The development of cracks and their location is confirmed by verification calculations. Insufficient amount of reinforcement led to deformations in the foundation walls, as the existing class of concrete $(\mathrm{C} 16 / 20)$ is not able to absorb such tensile forces. The location of the reinforcing bars in the grids of the footing is greater than the design requirements. 


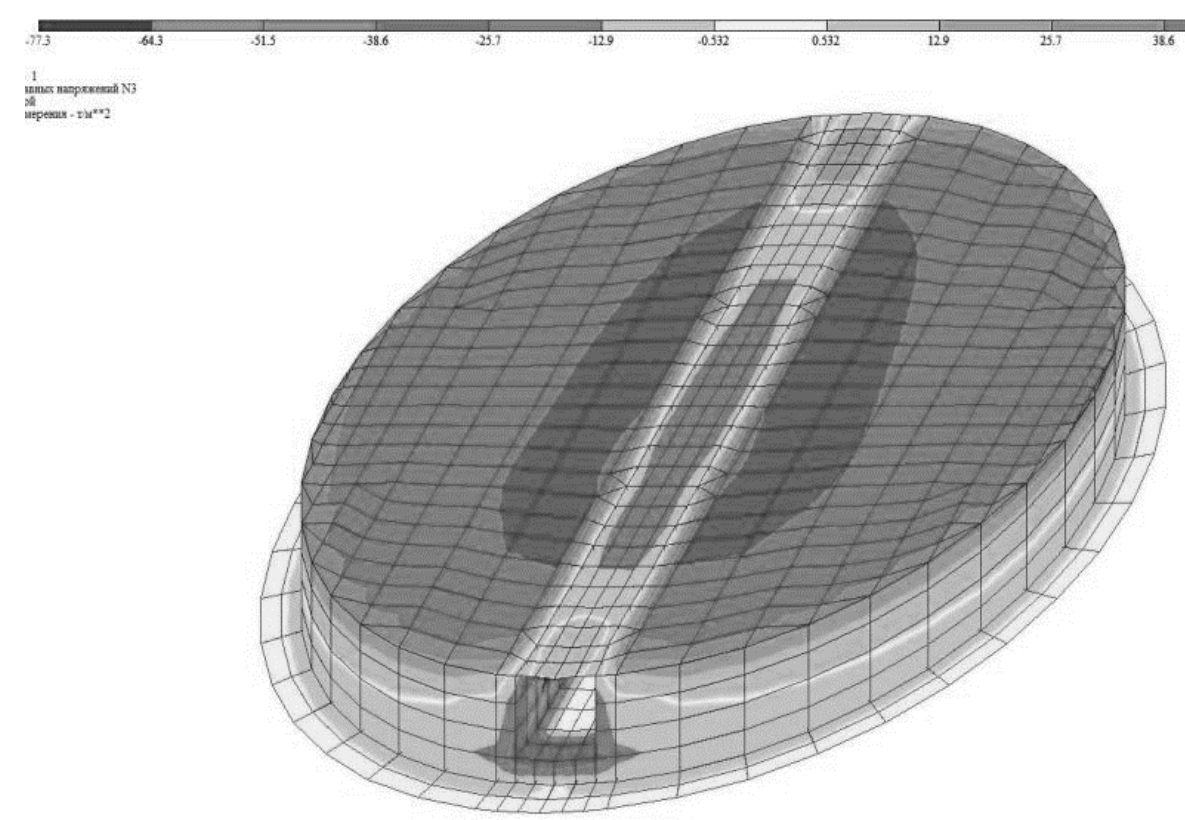

Fig. 8. Isopolies of main stresses

For further safe operation of the structure, it is recommended to reinforce the walls of the foundations by gluing composite tapes (Fig. 9) and perform reinforcement of the foundations by piles (Fig. 10) according to the additional working design of the structure reinforcement.

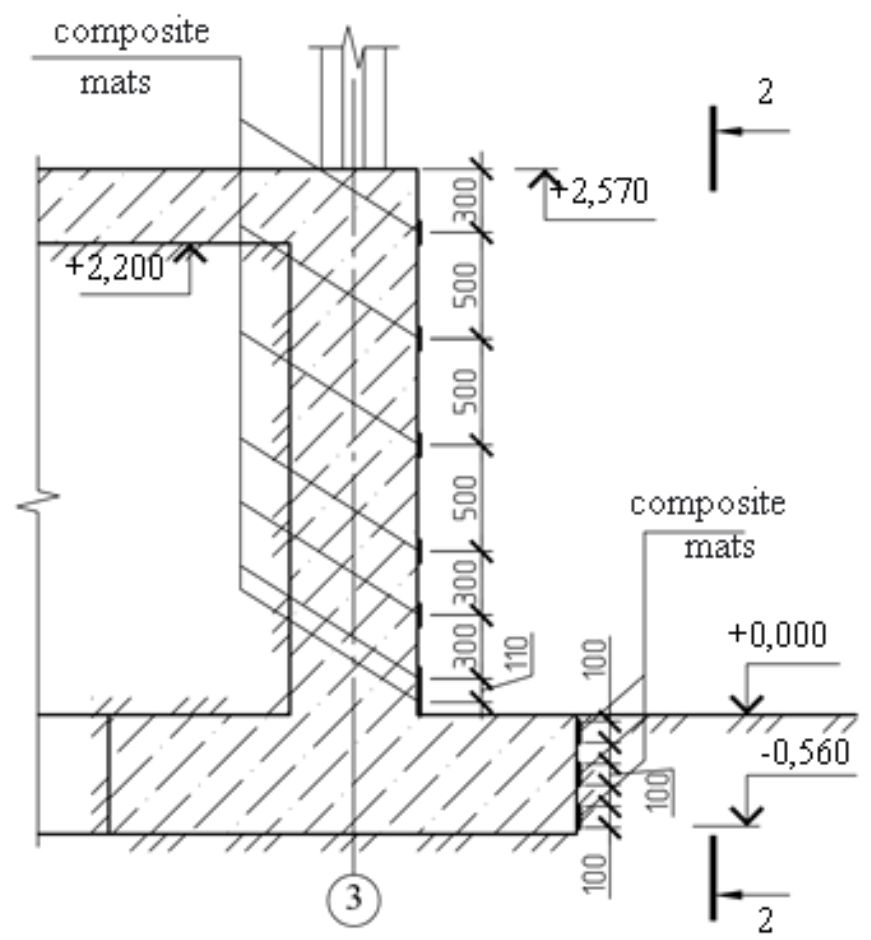

Section 2-2

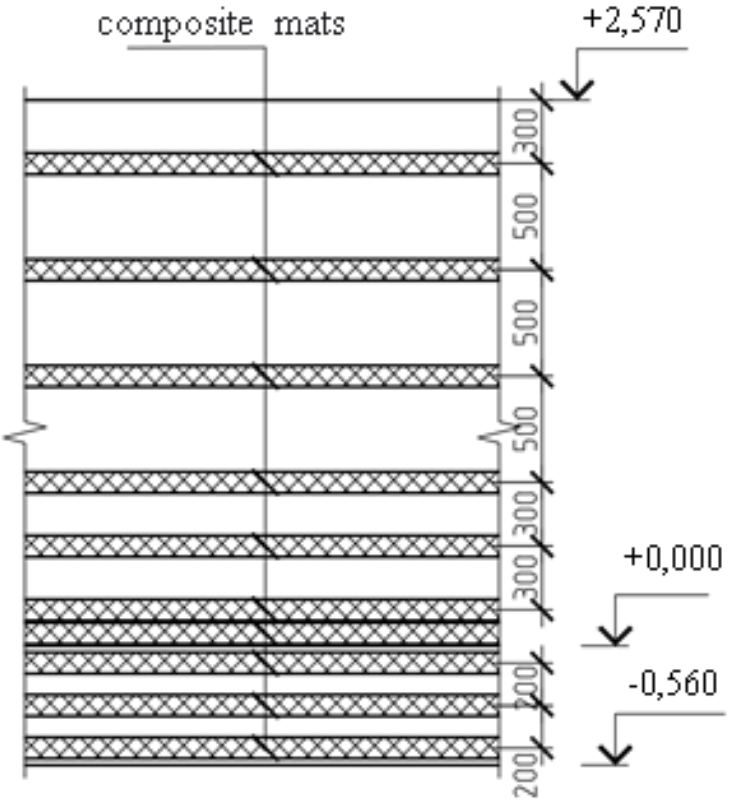

Fig. 9. Proposal to reinforce the damaged walls of the reinforced concrete foundation with composite tapes 


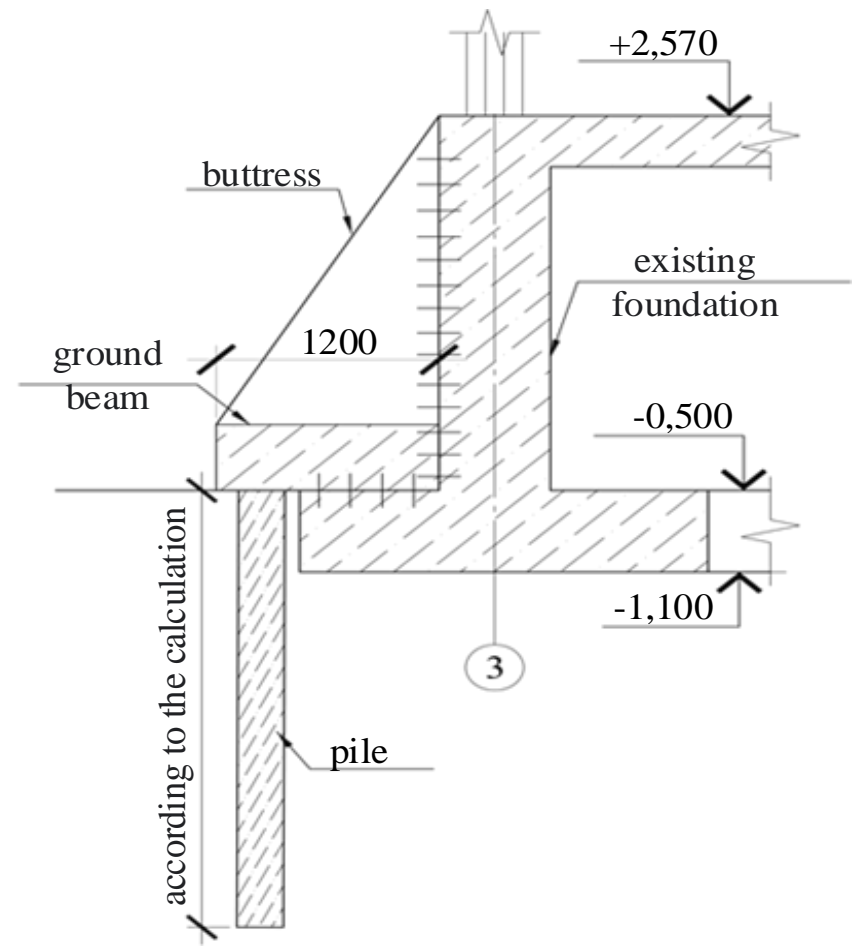

Fig. 10. Proposal to reinforce the damaged reinforced concrete foundation by means of piles

If the latest recommendations on strengthening and adhering to the safe and reliable operation of construction and structures are followed, further operation of building structures will be safe.

Conclusions:

1. Engineering facilities for storage of dry mixtures, liquids, feed, including the silo considered in this work, occupy a significant place in the industrial sector, so their repair, reinforcement and maintenance for further operation should be given due attention, involve design organizations with appropriate experience and design and technological developments in the reinforcement and reconstruction of engineering structures.

2. Execution of strengthening of the monolithic foundation according to the developed offers will provide durability and reliability of a design, and also the normalized service life according to requirements of current design norms.

\section{References}

[1] DSTU N B V.1.2-18:2017. Nastanova shchodo obstezhennya budivel' i sporud dlya vyznachennya yikh otsinky ta tekhnichnoho stanu. Kyyiv: «UkrNDNTS», 2017.

[2] DBN V.1.2-14:2018. Systema zabezpechennya nadiynosti ta bezpeky budivel'nykh ob"yektiv. Zahal'ni pryntsypy zabezpechennya nadiynosti ta konstruktyvnoyi bezpeky budivel' i sporud. Kyyiv: Ministerstvo rehional'noho rozvytku, budivnytstva ta zhytlovokomunal'noho hospodarstva Ukrayiny, 2018.

[3] DBN V.2.2-8-98. Pidpryyemstva, budivli i sporudy po zberihannyu ta pererobtsi zerna. K.: Derzhbud Ukrayiny, 1998. $41 \mathrm{~s}$.

[4] Vidnovlennya ta posylennya sylosiv, rezervuariv ta bunkeriv dlya dribnozernystykh materialiv. [Online]. Available: http://bibliograph.com.ua/spravochnik-120-zhbizhelezobeton/72.htm.

[5] DBN V.2.6-98:2009. Konstruktsiyi budynkiv i sporud. Betonni ta zalizobetonni konstruktsiyi. Osnovni polozhennya. K.: Minregionbud Ukrayini, 2011.

[6] ENV 1992-1-1:1991: Eurocode 2. Design of concrete structures. Part 1-1: General rules and rules for Buildinigs: European Prestandart.

[7] V.V. Kachurenko, D.O. Bannikov, Konstruktivnyê resheniya stal'nykh yemkostey dlya sypuchikh materialov. Monografiya. Dnepropetrovsk, 2016. 
[8] Tekhnichnyy zvit "Obstezhennya ta vyznachennya tekhnichnoho stanu zalizobetonnykh fundamentiv ta sylosu TzOV "Ahro LV Limitet" v s. Vyriv Kam"yanko-Buz'koho rayonu i rozrobka rekomendatsiy z podal'shoyi bezpechnoyi ekspluatatsiyi", L'viv: NDL-19, Natsional'nyy universytet «L'vivs'ka politekhnika», 2012.

[9] Normatyvni dokumenty z pytan' obstezhen', pasportyzatsiyi, bezpechnoyi ta nadiynoyi ekspluatatsiyi vyrobnychykh budivel' i sporud. Kyyiv: Derzhavnyy komitet budivnytstva, arkhitektury ta zhytlovoyi polityky Ukrayiny.1997.

[10] I.H. Ivanyk, S.I. Vikhot', R.S. Pozhar, Ya.I. Ivanyk, Yu.Yu. Vybranets', Yu.I. Ivanyk, Osnovy rekonstruktsiyi budivel' ta sporud. Navchal'nyy posibnyk. Vydavnytstvo L'vivs'koyi politekhniky, 2018.

[11] YE.M. Babych, V.V. Karavan, V.YE. Babych, Diahnostyka, pasportyzatsitsya ta vidnovlennya budivel' i inzhenernykh sporud. Pidruchnyk. Rivne: Volyns'ki oberehy, 2018.

[12] DSTU B V. 2.6-2:2009. Konstruktsiyi budynkiv i sporud. Vyroby betonni i zalizobetonni. Zahal'ni tekhnichni umovy. K.: Minregionbud Ukrayini, 2010.

\title{
ОЦІНКА НЕСУЧОЇ ЗДАТНОСТІ КРУГЛОГО В ПЛАНІ ЗАЛІЗОБЕТОННОГО ФУНДАМЕНТУ ПІД СИЛОС
}

\author{
${ }^{1}$ Вибранець Ю.Ю., к.Т.Н., \\ yura.vybranets@gmail.com, ORCID ID: 0000-0002-3842-9780
}

${ }^{1}$ Віхоть C.I., к.T.H.,

vixot@ukr.net, ORCID ID: 0000-0002-1063-2103

${ }^{1}$ Начіональний університет «Львівська політехніка» вул. С. Бандери, 12, м. Львів, 79013, Україна

${ }^{2}$ Бурченя С.П., К.Т.Н., nedostup@i.ua, ORCID ID: 0000-0002-6903-1134

${ }^{2}$ Львівський наиіональний аграрний університет вул. В. Великого, 1, м. Дубляни, 30831, Україна

Бабяк І.П., К.т.н., с.н.с. igorbabyak@meta.ua, ORCID ID: 0000-0002-3732-2439 ${ }^{3}$ Державне підприємство «Держсавний дорожсній науково-дослідний інститут ім. М.П. Шульгіна» пр. Перемоги, 57, м. Київ, 03113, Україна

\begin{abstract}
Анотація. При проектуванні, монтажі та експлуатації силосів в них виникають дефекти i пошкодження різного характеру, які впливають на напружено-деформований стан i довговічність конструктивних елементів. Своєчасне проведення обстежень та визначення технічних станів конструктивних елементів споруди і об'єкта в цілому, дозволить встановити можливість його подальшої безпечної експлуатації або необхідність відновлення експлуатаційних властивостей шляхом забезпечення конструктивної безпеки і надійності споруд. Тому розробка розрахункових схем, методик розрахунку напружено-деформованого стану, прогнозу терміну служби і подальше підсилення для круглих залізобетонних елементів силосів з локальним пошкодженням, є досить актуальною.

Неналежне утримання і експлуатація конструктивних елементів, а також помилки допущені при проектуванні і монтажі, в подальшому призводять до непридатного до нормальної експлуатації, а часом і до аварійного стану. Розробка проектів підсилення існуючих конструкцій $є$ досить відповідальною справою. Найбільш поширеним рішенням підсилення існуючих фундаментів є збільшення площі обпирання подушки фундаментів, що не завжди можливо в умовах стиснутої забудови.

Метою роботи $є$ визначити технічний стан будівельних конструкцій силосу і за результатами проведених в ПК Ліра розрахунків, запропонувати варіанти підсилення фундаменту на конкретному прикладі.

Наведено конструктивні рішення залізобетонного монолітного фундаменту під стіни силосу, основні дефекти і пошкодження, визначено технічний стан споруди. Для подальшої безпечної експлуатації споруди рекомендується зробити підсилення стін фундаментів за допомогою наклеювання композитних стрічок і виконати підсилення фундаментів за допомогою
\end{abstract}

Bulletin of Odessa State Academy of Civil Engineering and Architecture, 2021, no. 83, page 28-37 
влаштування розпірних паль, згідно додаткового робочого проекту підсилення споруди. При виконанні рекомендацій щодо підсилення та дотриманні положень про безпечну та надійну експлуатацію будівель і споруд подальша експлуатація будівлі в цілому буде безпечною.

Ключові слова: залізобетонний монолітний фундамент, стінки фундаменту, силос, підсилення.

\title{
ОЦЕНКА НЕСУЩЕЙ СПОСОБНОСТИ КРУГЛОГО В ПЛАНЕ ЖЕЛЕЗОБЕТОННОГО ФУНДАМЕНТА ПОД СИЛОС
}

\author{
${ }^{1}$ Выбранець Ю.Ю., к.Т.Н., \\ yura.vybranets@gmail.com, ORCID ID: 0000-0002-3842-9780 \\ ${ }^{1}$ Вихоть С.И., К.Т.н., \\ vixot@ukr.net, ORCID ID: 0000-0002-1063-2103 \\ ${ }^{1}$ Нациинальный университет «Львовская политехника» \\ ул. С. Бандеры, 12, г. Львов, 79013, Украина \\ ${ }^{2}$ Бурченя С.П., к.Т.Н., \\ nedostup@i.ua, ORCID ID: 0000-0002-6903-1134 \\ 2 Львовский национальный аграрный университет \\ ул. В. Великого, 1, г. Дубляны, 30831, Украина \\ ${ }^{3}$ Бабяк И.П., К.Т.н., с.н.с., \\ igorbabyak@meta.ua, ORCID ID: 0000-0002-3732-2439 \\ ${ }^{3}$ Государственное предприятие «Государственный дорожный научно-исследовательский \\ институт им. М.П. Шульгина» \\ пр. Победы, 57, г. Киев, 03113, Украина
}

\begin{abstract}
Аннотация. При проектировании, монтаже и эксплуатации силосов в них возникают дефекты и повреждения различного характера, которые влияют на напряженнодеформированное состояние и долговечность конструктивных элементов. Своевременное проведение обследований и определения технических состояний конструктивных элементов сооружения и объекта в целом, позволит установить возможность его дальнейшей безопасной эксплуатации или необходимость восстановления эксплуатационных свойств путем обеспечения конструктивной безопасности и надежности сооружений. Поэтому разработка расчетных схем, методик расчета напряженно-деформированного состояния, прогноза срока службы и дальнейшее усиление для круглых железобетонных элементов силосов с локальным повреждением, является весьма актуальной.

Ненадлежащее содержание и эксплуатация конструктивных элементов, а также ошибки допущенные при проектировании и монтаже, в дальнейшем приводят к непригодности к нормальной эксплуатации, а порой и к аварийному состоянию. Разработка проектов усиления существующих конструкций является достаточно ответственным делом. Распространенным решением усиления существующих фундаментов является увеличение площади опирания подушки фундаментов, что не всегда возможно в условиях сжатой застройки.

Целью работы является определить техническое состояние строительных конструкций силоса и по результатам проведенных в ПК Лира расчетов, предложить варианты усиления фундамента на конкретном примере.

Приведены конструктивные решения железобетонного монолитного фундамента под стены силоса, основные дефекты и повреждения, определено техническое состояние сооружения. Для дальнейшей безопасной эксплуатации сооружения рекомендуется сделать усиление стен фундаментов с помощью наклеивания композитных лент и выполнить усиление фундаментов с помощью устройства раскосых свай, согласно дополнительного рабочего проекта усиления сооружения. При выполнении рекомендаций по усилению и соблюдении положений о безопасной и надежной эксплуатации зданий и сооружений дальнейшая эксплуатация здания в целом будет безопасной.
\end{abstract}

Ключевые слова: железобетонный монолитный фундамент, стены фундамента, силос, усиления.

Стаття надійшла до редакції 23.03.2021

Bulletin of Odessa State Academy of Civil Engineering and Architecture, 2021, no. 83, page 28-37 